\title{
A Colonial Worldview in E.M. Forster's A Passage to India
}

* Nijat Ullah Khan, PhD Scholar

** Abdul Hamid Khan, Assistant Professor

\begin{abstract}
This paper aims to analyze the colonial worldview characteristic of the friendship between the English and the Indians in the early 20th century represented in E. M. Forster's novel A Passage to India. The socio-cultural contacts between the British colonizers impersonated in the novel as the British characters and Muslim Indians as the colonized group is studied in detail. Applying Franz Fanon's psycho-political perspective the paper focuses on conflicting situations between two groups of characters in the novel. The paper focuses on the colonial worldview and its effects on the relations described in the novel are represented through the situations of misunderstanding and alienation that result in chaos. The study found that the hostile and discriminate approach of English men toward the Indians never let the relationship flourish. The study however, shows some positive signs, as the author has criticized the attitude of the English. This paper suggests further research into Forster's novels from different literary perspectives to investigate the psyche and its effects on human relationships.
\end{abstract}

Keywords: Colonial worldview, Franz Fanon's psycho-politics, British Empire, Indians, power

\section{Introduction}

The paper attempts to examine the novel, A Passage to India from psycho-political perspective so as to determine the impacts of colonial psyche upon the affiliation between the colonists and the inhabitants in India, and to investigate the politics of power that leads to trauma and alienation (Hook, 2004). Using this theoretical framework, this paper intends to explore the colonial psyche in the novel, and to analyze the effects of this psyche in establishing human affairs.

Forster is one of the leading literary figures of twentieth century. His critical gaze and deep study of the locals and their social norms gave him first-hand knowledge particularly about India and the Indians. Nonetheless, he happened to have a critical gaze on the rising conflicts, the stress and strain in India between the rulers and the ruled, and was serious in disclosing the factors held responsible for these instability and annoyance in the novel. (Amina, 2006)

\section{Statement of the Problem}

The paper explores the psyche of English men and women, and the role that it plays in determining the relationship with Indians. The paper examines the situations where the English and the Indian interact with each other, so as to know how their political psyche operates in terms of ideological assumptions, cultural misunderstandings, and psychological crises, and to what extent the relationships remain dotted.

\section{Literature Review}

Critics and scholars have studied A Passage to India from different standpoints. Abu-Bakr (2006) investigated that English as being strict and aggressive is somewhat true because it was distinct from their imperial motto too, and the way they talked and behaved towards the Indians; hence they suppressed the innocent, considered them as inhumane, uncivilized, and

\footnotetext{
* Department of English, Qurtuba University, Khyber Pakhtunkhwa Peshawar.

Email: shahnijat@googlemail.com

** Department of English, Qurtuba University, Khyber Pakhtunkhwa Peshawar.
} 
wild folk. This psyche might be the result of their so-called notion that they were in India for the purpose of civilizing the harsh, unpolished and impolite natives (Pirnuta 2001). Hawkin (2001) identified the same thing in the rulers, and says the Indian is an infant child to them who needs someone to take care for. It shows that the English made decision for the Indians, protected India from foreign aggression, as to them, they were incapable of confronting the aggressors, and further, they did not have the ability to make laws and run the government. Forster (1953) also raises the same stance about the colonial consciousness that the English have turned impassive, persistent and hardhearted by being in India.

Memmi (1965) states the reasons of their stolid attitude and superior way of thinking. She argues that that the colonizers might be influenced from the Darwin's theory of survival of the fittest, for they kept on pressing and killing the native for their hidden economic motives. This thinking might have compelled them to occupy, and to colonize the less powerful and to rule them for political and economic interest.

Boehmer (1995) too identifies the same ideology in the white race saying that they occupied the foreign land to use their sources, and to exploit their lands and labor. This practice can invariably be seen in the novel on different occasions where the sense of otherness, superiority and ambivalence is felt so as to avoid intimacy and utilized their energy for their uplift.

Abu Baker (2006) argues that it was this kind of exploitation that not only the Indians but the land of India even becomes hostile to them. He further declares that, in reaction to the colonizers' oppression and considering them inferior, and themselves as being the white man brought confrontation and chaos.

Amina (2006) also traces the elements of arrogance in the English as those of the Romans who once thought themselves to be the chosen and the shielded. She associates their notion of being superior to their old claim that they might have been inspired from the Roman as they thought themselves the inconvincible and the undefeatable like those of Romans.

Catarina (2004) connects their psyche to their promising economic and political conditions in the world. As soon as they became wealthier, they turned to be cruel, and insular which altered their behaviors of governing the realm and treating the locals, because they began to think that the empire was vital for Britain. Furthermore, their economic hegemony converted their mission into ambition, and by dint of this way of thinking, they cogitated the local to be the scum of the earth. In reaction, the native turned against them which resulted in distress and fright in the country.

Tayyab (2010) traces the effects of their mindset on the Indian social atmosphere. Jeffrey (1998) sees the impact of such way of thinking during the trial scene when they were bent upon holding Aziz as guilty, as Amina (2006) also observes the same wave of abhorrence and preeminence, as they imagined themselves to be the quintessence of intellect and astuteness. They ruminate themselves as the bosses, so they are right and justified what they do or say. She elucidates this position of the English by saying that they actually wanted conform to the Whiteman's burden theory as they imagined themselves that it was only they who could assist the wretched, and could certify the righteousness by observing the commandment and order in the areas in their hold.

The English's behavior on different occasions accords to their belief of being the superior and more civic. Amina (2006) considers this way of thinking against the Whitman's dream (1871) of connecting the East to the West as fantasized by Kipling (1899), who visualizes the opening of the Suez Canal connecting the Eastern to Western sea. However, in such situations with this psyche, it seemed quite improbable.

Bhabba (2012) also examines the shrewd defiance and the colonial spirit in the English men and women. He considers that the royal and colonial construction erects a needless wall on the smooth way of individual and social dealings. The variance, as Lehman 
(2007) calls the apparition of oddness goes through all the human associations in the novel, takes to a failure

Their imperialistic, colonial outlook and psyche created doubts in the Indians' mind. Hence they were not certain whether to trust the English or not (Elitas, 2006). Aziz and Mahmoud Ali are forced to think that the English cannot be their friends. His reluctance of being his friend shows ambivalent emotions shared by both the nations which accounts for their behavior (Stone, 1966).

Safavina (2007) appropriately recognizes the situations that there can be no apposite social joining in the subjugated nation. Nevertheless, there are pint-sized rudiments in the societal structure which force them to form acquaintances with each other through the barricades of mistreatment and the callous imperatives. However, tangible discernment can be fingered very noticeably, exclusively when two human actualities come into contact.

The aforementioned discussion illustrates that colonial worldview and the imperialistic outlook developed in the English was due to their social, political and hegemonic economic stability. More importantly, their incessant victories at different fronts made them think themselves as superior race. Precisely, they belonged to the Europe so they thought to be more civilized and nobler than the Indians. Their Eurocentric and universal dogmas gave them the idea that they are the right people to rule while the people in resided in the colonies are barbarians. They would tear out one another if they were left un-ruled. This expatriates the psyche of the foreigners which befall negative effects on the locals which will be explored in the analysis.

\section{Theoretical Framework of the Study}

The paper is theoretically backed by Fanon's theory of psychopolitics. He explains how human psychology is closely connected to sociopolitical forces (Dowbiggin, 1997). In the coinage of psychology and politics, he exhibits the effects of colonial violence on the mind and behavior of the colonized and holds this psyche responsible for the worse relationships.

Hook traces this notion in his book, The White Masks and Black Faces (1986) during the analysis of the psychological effects colonial subjugation on people who was superior to them. Fanon examined the sense of dependency, inadequacy and powerlessness of the Indian people under the colonial regime. His investigation of psychic life of the colonials dramatizes the logic of the colonial psyche and power, and particularly that of colonial racism (2004). Fanon declares he suggests, that has numerous negative psychological effects are realized not only in the dreams of the colonized but also in the psychic life of the colonized (Adam, 1970).

It was Fanon who identified the White's use of ideological loaded Eurocentric, oppressive, racist and colonial power exercised over the feeble and the subjugated in the colonized land. He also recognized the colonial notion of scapegoat how the oppressed were made responsible and guilty for the crimes which they had not committed as can be seen in trial scene of the novel when Aziz was being held punishable to avoid the feelings of guilt and responsibility. Franz Fanon is fully bizarre of this projection of the white (Legman quoted by Hook 1970). Such psyche of the White is projected in this paper.

Fanon focuses attention largely on the colonized, eminently enquiring, through Freud, "What does the black man want?", whereas Bhabba's concern is with balancing this attention on the oppressed with an attention to the desire of the colonizer, with implicitly asking ,what does the white man want? (Adam, 1970).

\section{Methodology}

Descriptive qualitative research is the design of the study. It explored the attitudes, concerns, behaviors and the worldview of the English characters. Close reading techniques are used for collecting data in A Passage to India. The worldviews are discovered from the English men's and women's psyche through their attitudes and manners as shown in the novel. In order to 
reveal the role of psyche and mindset in human contacts, this paper looks at the events, speeches and the behaviors, actions and reactions of the colonizers at different occasions in the novel. Besides, the paper is viewed from Fanon's perspective of psychopolitics to examine the effects of the colonial psyche. It also underpins how the political power makes the ruler more arrogant, and how such psyche affects the relationship between the rulers and the ruled, will be examined.

\section{Discussion and Analysis}

This section of the paper discusses and analyzes the text from different parts of the novel to detect the effects of the psyche of English men and women on human relationships. Undoubtedly, human psyche plays a significant role in establishing relationships. This chapter has focused on the textual discussions to explore its impact on the contingency of relationships between the locals -the Indians and the foreigners - the English. It has disclosed the factors how human relationships are disturbed by unconstructive psyche and amorphous mentality.

Nonetheless, misunderstanding and off-putting way of thinking divided both internal and external disorder and resulted in total annihilation of individual as well as of the society in A Passage to India (1924). Indians were bizarre of the insolent, snobbish and despotic behavior of the white which kept both the nations at distance. The English men and women's psyche largely emanated from their words, speeches, gestures and actions are observed on different occasion in the three parts of the novel named the Mosque, the Caves and the Temple.

Ronny Heaslop is a representative English authorized when he says that he is the sun desiccated administrator, undoubtedly he does not want an English lass in the company with two Indians smoking (Forster, 1924:66). Mrs. Moore's first get-together with Aziz (23) is devastated by him when he, in a prickly and an overbearing way, questions her who let her come in the mosque with her shoes. Then it was impertinence. It's an old artificiality. His call meant that she should have had shoes on (12). Ronny's outlook replicates his mind (Safavina, 2007). His confrontations reveal his worldview that the position of the English man and women is similar to the master who issues only orders.

Ronny does not like Aziz, and thinks that Aziz can never be friendly. Generally, he is a creature, good for nothing (Forster, 1999:53). Mrs. Moore is traumatized to see him, and thinks him to be devoid of humanity. She holds responsible the British way of governing for his son's indifference and unkindness. It seems to her that it is this of ruling that her son has become insensitive (Forster, 1999:70). She is also shaken to know her son's ideological stance, for which she taunts him that he was not sort of person to judge people like this in England. Ronny unaffected by her mother's derision says that India is not home (54) and they are not in there for the commitments of amusing people. They are there to ensure uprightness and keep the peace (69).To Ronny, being good to the inhabitant is a side matter (68).

Turton's words that in India the English unconsciously behave English and transfigure consciously English in England, divulges his mind set (Childs, 1992). Further, Benita exposed the psyche of the English young men and women snubbing the residents in the similar humorous way until they were pushed to the attributed subjects by the time, the snub English men were mocking the Indians in Adela's presence (1985).

During the trial scene, Benita (1985) rightly argues that every social act in the East is discolored with bureaucracy, and the system where there is such administration, every social relation agonizes, where man feels in elevation and treats others with triviality and selfimportance. Ronny seems to be the representative of this system who very straightforwardly shows these personas of expansionism and bureaucracy.

Major Callendar disturbs Aziz in his dining, and breaks up a most enjoyable 
entertainment (Forster, 1999: 15). During the trial, he attempts to corroborate Aziz as illicit by discontinuing Adela's confession at the court on medical explanations (207). His being is resounded in his detestation against the Indians when he calls them as Hogs, and craved to put the dread of God into them at the hospital anyhow and his account of Nureddin's present look that 'His attractiveness has gone, five higher teeth, two junior and a nostril. And he laughed (203-204).

At Bridge party, Callendar discovers liability in Indians when he keeps talking that he knew something to the disrepute of almost each one of his visitors and was subsequently careless (Forster 1999: 45). However, the party recoils as pathetic, and makes Mrs. Moore annoyed and unhappy, so she is enforced of considering her countrymen to be mad (36). Amrit Rao is reproached by the Major in the court, roaring and ordering him to cut the laugh and let the judgment be started (224) exhibits his inner self. At the party, Mr. and Mrs. Turton humiliating and ridiculing the Purdah women (47) fully exposes their mind what and how they think of the locals saying that the ladies are superior to them, but, they should not forget that they are superior to everyone in India except one or two of the Ranis (52).

The purported rape of Miss Quested brands the minds of her compatriots even worse. Here Franz Fanon's view of scapegoat (2009) is seen nearly when the Collector tries to make Aziz punishable when he cries in the court about the White's Eurocentric view of British virtue and righteousness as he tempts the white "for the good old days when an English could satisfy his own honor and no questions asked afterward" (2009) and each felt that all he loved best in the world was at stake, needed retaliation, and was packed with a not unpleasing ruddiness, and the unfriendly and half-known features of Miss Quested is seen to be disappeared and were substituted by all that is sweetest and heartfelt in the isolated life (183). So it is not astonishing that they are completely ashamed and annoyed when Adela admits that Dr. Aziz 'did not follow her into the Malabar caves after all.

Once, Dr. Aziz's lawyer named Mahmoud Ali speaks to the Indian judge that he is not defending a case, nor she should be trying one. They are slaves after all (Forster, 1999:224). Though he is expelled from the court house for his clarifications, it showed the failure of evenhandedness in colonial India, along with the ethical disappointments and twofacedness of the colonial establishment.

Furthermore, McBryde's psyche in Aziz's trial is shown at the court when Mahmud Ali inquired the judge to permit his client to sit on the stand; the magistrate overturns by calling him Pleader, Mahmud Ali now gets up (223). The magistrate's actions is more noticeable when he forces him to take off his glasses, as it is his habit before pronouncing overall certainty, he stares at them sadly, and remarked that the duskier races are actually fascinated by the fairer but not vice versa (222).

The groundless terror, animosity, intolerance and imperialistic arrogance in McBryde's heart and mind appear in full blow at the court trial when he calls the Indians as the deprived and the worthless natives (Forster, 1999). The whole English folk stand on the line against Aziz as clearly expressed by McBryde crying that the mind here is diverse. He contemplates that the natives as sub- species, imagining wrongdoing sideways ethnic positions (151). His psycho-political thinking blinds him to see the innocent and the guilty as redundant: Indians do not share a social nature with the English, and therefore, Indian behavior cannot follow to British codes of courtesy.

This shows their phobia and Ambivalence - a phenomenon Fanon rightly mentioned in his White Mask Black Face (1986) that powerful emotional responses appear to coincide with conflicting affective impulses in such circumstances as the English justice structure, in Chandrapore, is reliant on race or, more exactly, on racial edifice and not on evidences, and their anger to see Indians as embarrassed unless upheld guiltless, the trial should hoard all possible proof, however sloppy. "We are meant to be horrified not only by the complete 
invasion of Aziz's privacy”. (125)

Dolin (2009) argues that McBryde's zeal in formulating the Anglo-Indian description of how Aziz was supposedly held responsible for Adela's harassment alone exposes his bias. We are told that he and Fielding had both visited brothels when they were of Aziz's age. Whereas they remained unpunished by law, this same law will likely punish Aziz for two crimes (engaging a prostitute and raping a woman) that he did not, in fact, commit. Forster depicts both McBryde and the legal system more broadly as hypocritical and unjust. In his note to Fielding, he calls the verdict as "disaster result"e and declares that no courtesy, by all means or intimacy - never, never to the Indians and sees that the outcome of the case as "the work of years is undone" (Forster, 1999:174).

Adela' psyche is revealed when Aziz is accused, and because of her, his life becomes impoverish and anguished at the hands of the English. However, her blame reveals the White man and women's phobia, eurocentrism and universalism when they think it as an insult to the whole race (Fanon, 2009). Adela is fixed in twofold standing as lesser sex but Superior race. She is incapable to choose what to sort out: whether to voice in good turn of Aziz or not (203).

At this stage of the novel, Forster projects himself as a humanist, and he has to acknowledge that imperialistic and colonial gaze and psyche have really loosened the British control, and they have lost the Indian sympathy, and have upset the individual relations (Forster, 1999:284). Fielding's psyche, his tactics and discourses similar to the colonial psyche exposes him. Ngügï (2003) calls this way of treatment as the social explosive which generates grave misgivings about the ethical suitability of skirmish, and makes the potentials of achievement or win seem as inaccessible, or ludicrous. He argues that Aziz, and the other Indians were the second-rate citizen as compared to the British, hence the Indians were forced go to the kernels at once.

Fielding uses the imperative tone to remind Aziz that he is inferior to him. He delineated an amusing salutation. His motion said that it was not misplaced upon Fielding (296). His comic greeting refers to the greeting demand that the British executed after the Amritsar massacre of 1919, which was necessary for all the Indians to greet or respectfully salute the English civilian and constables (180). He is not even permitted to sense bigger to them (303).

Fielding's psyche, his maneuvers and discourses comparable to the colonial psyche discloses him. Ngügï (2003) calls this mode of behavior as the racial booby trap which produces stern reservations about the ethical relevance of fight. Forster (1999) himself makes it clear that in India, the possibilities of triumph or victory appear as remote and ridiculous dreams (314).

Further, that it is nobody's India (Forster, 1999:273) undermines any prospect of India ever becoming a nation. Degan (2008) further evaluates his position uncertain when he weds Stella, his compatriot, and his imploring for Ronny that he had no uttermost usage for civility meaning that the British Empire cannot be eliminated since it is impolite. (255). His psyche is well revealed when he claims that no native can outflow his genesis and no white man can escape his white blood.

As exposed from the insolence of the English, it is clear now that the expedition of one nation, particularly the dominant one into the heart of the ruled miscarried because of the British conceited and narrow-minded behavior. The English representatives watched the Indians from the viewpoint of dominance, so they were biased, puffed-up and disdainful (Memmi, 1965). Mr. Turton though stressed on the requirement of fairness and integrity but as an authorized he does like to be civil to the Indians but not open and welcoming to them (Forster, 1999: 215). McBryde did not need these things to understand India. Indians, to them, were crooked by nature, untrustworthy and devious. The drunken Major was induced 
that the Indians knew only the language of power.

A few English like Fielding and Mrs. Moore tried to understand India and the Indians. They transferred attachment, lenience, shared deference and understanding (Amina, 2006). Yet, Mrs. Moore did not assist the Indians vigorously apparently in the court. Aziz obviously professed that alliance between social groups could be permanent where rapport between uneven could not bear for long (Forster 1999). The two horses ran in dissimilar ways (316) which presented that the correlation between two cultures grounded in smugness, inequality, superiority, and fears could never last.

Adam (1970) states that whether we like or not, the colonial worldview is revealed in the courtroom. Adela's reappearance to intelligibility is understood by Fielding as a uneasy collapse, however, the point remains that she was under promise when she fully professed, and expressed the truth. The psyche is meticulously is bare when Adela was kept away from the truth when she was fenced by other English men and women who doubted the Indians, and that Indians partaking in the courtroom ceremonials understand that the rubrics of the court have made this result conceivable. All the interactions miscarry in this deleterious postwar novel; even the affiliations have curbs and deficiency of charms. Lehman (2007) states that the novel portrays man's efforts against the insignificance, however, it flops to settle whether the sprints were overwhelmed or not.

\section{Findings and Results}

The study found that the colonial psyche was exercised in the forms of insularity, verbal violence, arrogance and mental torturing. Second, their imperialistic and colonial viewpoint permeated sense of supremacy in them, so they initiated to ruminate themselves as logically competent to rule the fragile populates. Their imperialistic, colonial worldview and psyche shaped reservations in the Indians' mind. Its effects were realized when the question of trust, cordial relationship, and possibility of friendship, which put the relationship to test, and he has to say that there can be no friendship. Moreover, the colonizers' so called notion that they are certainly suitable to administer the inhabited, also has undesirable impression on the locals. Be it at the Bridge Party, Aziz's rage on Adela's question about the marriage or be the slogan outside the court, God bole's embarrassment at Fielding's words about his inability to run the college, or be at last stage of the novel when Aziz's Fielding's horses gallop apart; and most severe effect is seen when Aziz responds coldly to Fielding, and Aziz's cold response at the end of the novel, are the effects of the colonial psyche and the power politics. This paper explored Fanon's point of view too how it accords with Forster's view. In the game of power of politics, the rulers are on focus while the wronged are ignored, and Forster does so. A Passage to India projects the situations where the English are dominant and the Indians are under their wrath. This argument is also supported by Hook (2004) who also argues that the Europeans find greater space in the English novels.

\section{Conclusion}

To conclude, the English did not leave any chance of demonizing the Indians. Ronny Heaslop, a representative public institute child, made greatest efforts to disgrace the locals. Forster's attempt to bridge the gap between the English and the Indians seemed to fail, but he found the ground realities which were quite opposite of his humanistic approach. The colonial psyche stained with racial grudges, bitterness arrogance and enmity neither let the relationships develop nor left any hope of any friendship. The analysis also revealed Forster's colonial psyche too as in the remarks, it is felt. The study showed that relationships based on bias and arrogance gets worse to such extent that they can hardly be recompensed. Even the fervent Mrs. Moore and good hearted Fielding are unsuccessful to protect the deteriorating stalemates. Nonetheless, they try to retain these relations as minimal as possible. Whatever the case is, the paper found a positive signs too that that Forster did expose the colonial psyche, and clearly projected the situations which marred the whole relationships. 


\section{References}

Adams, P. L. (1970). The social psychiatry of Frantz Fanon. American Journal of Psychiatry, 127(6), 809-814.

Baker, A. M. A. (2006). Rethinking Identity: The Coloniser in EM Forster's A Passage to India. Nebula, 3(2), 68-85.

Bhabha, H. K. (2012). The Location of Culture. Routledge Publisher

Boehmer, E. (1995). Colonial and Post-Colonial Literature (2005 ed.).

Childs, P., \& Williams, P. (2014). An introduction to post-colonial theory. Routledge.

Daiches, D. (1960). The novel and the modern world.

Degan, Zeynep. (2008) "A Passage to India": Adopting E.M. Forster. Journal of Communication and Designs: Bilken University: Bilken. 28-33

Dowbiggin, I. (1997). Robins, R. S., \& Post, J. M. Political paranoia: The psychopolitics of hatred". Yale University Press. 66-68

Elitas, Y. (2006). Anglo Indian Reconciliation in A Passage to India and Kim as a Colonial Novel: Turkey: Yuzuncu University

Fanon, F. (2008). Black skin, white masks. Grove press.

Forster, E. M. (1936). Abinger harvest. Mariner Books.

Forster, E.M. (1999). A Passage to India: London and New York: Penguin Books

Gordon, J. B. (1985). The Third Cheer:" Voice" in Forster. Twentieth century literature, 31(2/3), 315-328.

Hook, D. (2004). Fanon and the psychoanalysis of racism.114-137

Hook, D. (2004). Frantz Fanon, Steve Biko psychopolitics, and critical psychology.

Jeffrey, M. L. (1998). Essay for novels for students. Gale: Journal of Literature and Language. Gale

Kieran, Dolin. (2009). "Freedom, uncertainty and diversity: The Critique of imperialist law in Passage to India", in Fiction and the Law: Legal Discourse in Victorian and Modernist Literature. Cambridge University Press

Kinnvall, Catarina. (2004)." Globalization and religious nationalism: Self, identity, and the search for ontological security. Political psychology, 741-767

Kipling, Rudyard. (1899) Whiteman's Burden. A source book. London and New York: Routledge,

Lehman, Zoe. (2007). The Colonial other in E.M. Forster's A Passage to India. Journal of ISSN. Quest

McDowell, David. (1989). An Illustrated history of Britain. England: Longman, .19-23

Memmi, A. (2013). The colonizer and the colonized. Routledge.

Pirnuta, O.A. (2001) Indians vs British Cultural Aspects in E. M. Forster's A Passage to India

Said, E. (1987). Orientalism. 3"* Ed.

T, Stone, W. (1966). The cave and the mountain: a study of EM Forster. Stanford University Press.

Walls, E. M. (1999). An Aristotelian reading of the feminine voice-as-revolution in EM Forster's A Passage to India. Papers on Language and Literature, 35(1), 56.

Whitman, W. (1870). Passage to India (No. 28). Haskell House Pub Limited. 